\title{
Hrvatska kratka priča i Antun Gustav Matoš
}

\author{
ABSTRACT. Sablić Tomić Helena, Hrvatska kratka priča i Antun Gustav Matoš (Croatian \\ Short Story and Antun Gustav Matoš). „Poznańskie Studia Slawistyczne” 7. Poznań 2014. \\ Publishing House Science and Innovate. pp. 297-306. ISBN 978-83-63795-79-5. ISSN \\ 2084-3011.
}

Antun Gustav Matoš has affirmed the Croatian short story and that is why his short story collections have initiated a major ,,breakthrough" in terms of this genre's reception. His narrative oeuvre includes the following collections: Iverje (Wood Shavings, 1899), Novo iverje (New Wood Shavings, 1900) and Umorne priče (Tired Tales, 1909). Depending on the type of motif, his short stories have been read as follows: 1 . stories about local people and events; 2 . humorous stories about people at home and abroad; 3. stories about unusual, unbelievable ,unreal” events; 4. stories of enchanting and yearning love; 5. lyrical cadenzas. His symbolic-grotesque-fantastic story Moć savjesti (The Power of Conscience) marked his entry into the world of narrative literature. In this story, the binary relationship between the theme and the motif is recognised in the gap between the world of wakefulness and the world of dreams, reality and fantasy, what is real and what is unreal, the actual life and the ideal life, the object and the subject. At the same time, however, Matoš is trying to unite these opposites. In his other short stories, unusual plots become an expression of a deep ontological crisis which engulfed the European culture and art during modernism. The maxim of modern art at the turn of the century is ,the world is a text": art is a subjective reconstruction of the world and therefore plots, with all their logical cause and effect relationships, are no longer important since they cannot express other spheres of consciousness. In his short stories, the bizarre plots were used by Matoš to join two worlds, the world of outward reality and the world of imagination, the empirical and the fantastic, the possible and the impossible.

Keywords: modernism; short story; Antun Gustav Matoš; plot; citation

Hrvatska je moderna posebno razdoblje u hrvatskoj književnosti na prijelazu iz devetnaestoga u dvadeseto stoljeće. Početak moderne vezivao se uz 
spaljivanje mađarske zastave 16. listopada 1895. i prosvjednu povorku studenata koju je predvodio Vladimir Vidrić, kasnije jedan od najpopularnijih pjesnika moderne. Neki studenti iz povorke osuđeni su na tamnice i otjerani sa zagrebačkog sveučilišta. Studij su nastavili u Pragu, Beču i Münchenu te su iz tuđine jasnije mogli ocijeniti stanje u hrvatskoj kulturi, politici, gospodarstvu. Književnost moderne nekoliko je godina starija od toga studentskog prosvjeda protiv bana Dragutina Khuena Héderváryja. Prvi tekstovi koji pokazuju odmak od realizma i najavljuju novi književni senzibilitet tiskani su već nakon 1890., kao npr. Leskovarova novela Misao na vječnost koja je objavljena u „Viencu” 1891. Časopisi koje pokreću mladi Zagreba, Praga, Beča („Hrvatska misao”, „Hrvatski salon”, „Život”, „Mladost”) okupljaju nove pjesnike, pripovjedače, esejiste. Književnost se okreće pojedincu i njegovoj osobnosti, njegovim strahovima, nemirima i strastima. „Hrvatski salon” (1898) i „Život” (1900/1901) značajni su prostori u kojima se objavljuju tekstovi u kojima se čita izrazita usmjerenost njihovih autora prema književnom sustizanju zapadnoeuropskih umjetničkih smjerova. Naziv ovoga razdoblja i njegova stilska obilježja ne smiju se u potpunosti izjednačavati s kulturno-političkim i naraštajnim pokretom hrvatske moderne organiziranim u Pragu i Beču između 1895. i 1903. godine u kojemu „mladi” ustaju protiv tradicionalista „starih”. Pokret čini praška skupina okupljena oko kulturno-političkog časopisa „Hrvatska misao”, bečko-zagrebačka skupina okupljena oko književno-umjetničke smotre „Mladost” te nadaška skupina koja se okreće gimnazijskom časopisu „Nova nada”.

Književnokritički diskurs hrvatske moderne razvija se u dvjema fazama. U prvoj, koja se vremenski podudara s trajanjem pokreta, prevladava programatsko-manifestna kritika, a kritički osvrti usmjereni su na analizu djela hrvatske književne tradicije. Praška se skupina zauzima za sociološko-psihološki pristup, a bečko-zagrebačka orijentirana je prema artističko-estetičkom aspektu. U drugoj fazi, koja traje do kraja razdoblja, težište je na djelima nastalima nakon 1900. godine, a središnje mjesto zauzima Antun Gustav Matoš s esejističkom kritikom temeljenom na opisivanju dojmova. Najreprezentativniji su hrvatski modernisti Ivo Vojnović, Janko Leskovar, A.G. Matoš, Dinko Šimunović, Fran Galović, Vladimir Vidrić, Milutin Cihlar Nehajev, Ivan Kozarac, Janko Polić Kamov i Milan Begović.

Hrvatska se književnost s početka dvadesetog stoljeća prepoznaje po različitim poetičkim meandrima koji prepletanjem realističkih, naturalističkih 
i ekspresionističkih poetičkih paradigmi kroz tekstove recentnih književnika nastoje intenzivnije proniknuti u individualna društvena zbivanja, u predjele mašte, intuicije, osjećajnosti i osjetilnosti. Nadalje, sve je naglašenija tematska usmjerenost prema različitim oblicima društvenog života kao što su odnosi u obitelji, analiza malograđanskog mentaliteta, ali i problematiziranje mogućnosti obnove nekih civilizacijskih tekovina, revolt, rasap objektivne slike svijeta, simultanitet, atomizacija i izolacija pojedinih slika, samoironija i grotesknost. Većina književnih povjesničara, kao što su Miroslav Šicel, Krešimir Nemec, Julijana Matanović, Katica Čorkalo Jemrić, u svojim književnopovijesnim raspravama na to upozorava.

U kratkoj prozi nastaloj tih godina sve su izraženije modernističke narativne strategije, a sustav asocijacija i motivacija likova sve je više označen unutarnjom strukturom njihove osobnosti, što posebno naglašava J. Matanović u raspravi Čitanje Kozarčeve Oprave ukazujući kako ova novela načinom ,izgradnje svog tematskog i izražajnog sustava postaje zahvalnim predloškom za uočavanje razlike između dva susjedna stilska perioda realizma i moderne. Stvaralaštvo jednog autora, u ovom slučaju Josipa Kozarca, kojeg se tako sigurno ulagalo u povijesni pretinac realističkog pisma pokazuje da podjela književnosti na odsječke između kojih se uzdizala čvrsta godina, najčešće preuzeta iz povijesnih udžbenika, nije najsretnije rješenje" (Matanović 1997: 98). K. Čorkalo Jemrić (2008: 112) u ogledu Psihološke novele - stvaralački uspon prema modernizmu u načinu strukturiranja likova u Kozarčevim novelama uočava modernističke strategije jer njega „ne zanima afirmacija u društvu nego pitanje sreće njegovih likova. Neobični su i netipični Marijan Lučić iz Donne Ines, sudac Vučetić iz Oprave, Vuković iz Mire Kodolićeve i Emilijan Lazarević iz istoimene novele. Još su osebujniji ženski likovi" (Čorkalo Jemrić 2008: 112). Činjenica je kako spomenuti autori iz Slavonije na prijelazu devetnaestoga u dvadeseto stoljeće jedan dio svojih kratkih proza tematski usmjeravaju položaju i ulozi žene u obitelji, a preko nje i u širem socijalnom okruženju. U njihovim tekstovima nije riječ o stvaranju portreta čudesnih ženskih zavodnica, koketnih i prijetećih fatalnih žena koje su preplavile hrvatski roman XX. stoljeća, već o ženama čija individualizirana pozicija u psihološkom, pa potom i u socijalnom, nizu narativnog teksta govori u prilog odmaku od realističkog razdoblja i predstavlja pomak prema strategijama modernističkog oblikovanja lika. 
To je idealan kontekst u kojemu će kratka priča doživjeti svoju punu afirmaciju i recepciju. Razdoblje moderne u kratkoj priči pronaći će idealnu formu za brojna umjetnička propitivanja odnosa konteksta i individualne egzistencije. Ona će procvat i zamah doživjeti unutar brojnih stilova koji će se u ovom razdoblju javiti, krećući se prema artističkom ili verističkom. S jedne strane nalaze se kratke proze „simbolističko-impresionističkog kruga” (Fran Mažuranić, Janko Leskovar, A.G. Matoš, Milivoj Dežman Ivanov, Branimir Livadić i dr.), a s druge su priče pisaca (Živko Bertić, Ivan Kozarac, Joza Ivakić, Josip Kosor, Franjo Horvat Kiš) u kojima tematika obuhvaća realne probleme, najčešće vezane uz neku sredinu, a stil povezuje realističke metode s modernim izrazom.

Janko Leskovar (2005: 57) zajedno s A.G. Matošem otvara hrvatsku književnu modernu, unatoč još uvijek dominantnoj realističkoj paradigmi. Njegova zbirka Pripovijesti iz 1917. sadrži pripovijetke koje je objavljivao unatrag dvadeset godina u vrijeme smjene dviju književnih poetika. Riječ je o pričama Misao na vječnost (1891), Katastrofa (1892), Poslije nesreće (1894), Jesenski cvijetci (1897), Priča o ljubavi (1900), Bez doma (1900), Izgubljeni sin (1903) i Kraljica zemlje (1905). Dominiraju u njima prikazi iscrpljenosti, pesimizma, misticizma, spiritualizma i snova, a opisima pejzaža oslikava se intimno stanje lika. Glavni likovi u navedenim pripovijetkama uglavnom su (polu)intelektualci, senzibilni i usamljeni učitelji koji su pasivni u društvenom životu. Vođeni intelektom i emocijom oni prodiru u same sebe često stojeći pred sudbonosnim odlukama koje ne uspijevaju realizirati zbog psihičkog opterećenja prošlošću ili uslijed vlastite neodlučnosti i nemoći. Na kompozicijskom planu susreću se dva vremena: vrijeme prošle zgode koja ima posljedice u sadašnjosti te vrijeme sadašnjosti u kojoj se neprestano tematizira prošlost i tako priječi svaku moguću budućnost. U Leskovarovu se načinu prikazivanja odnosa pojedinca i kronotopa prepoznaje Turgenjevljev i Flaubertov stil pisanja. Međutim, za razliku od nešto slojevitijega turgenjevljevskog zarezivanja u tkivo društveno-političkog trenutka, on se zaustavlja na opisima pojedinačnih sudbina. Đuro Martić, učitelj u Druškovcu, amblem je Leskovarova usamljenog, nestabilnog, preosjetljivog muškarca koji živi između snova, halucinacija i stvarnosti. Zaokupljen je razmišljanjima o svijetu kojim je okružen, mašta o svemiru u kojemu je zapisana i njegova sudbina, zaljubljuje se u mladu učiteljicu iz susjednog sela. Pri svemu tome duboko je 
nesretan i neprilagođen, što ga i dovodi do krajnjega psihičkog rasapa koji je sublimiran u zaključnoj, antologijskoj rečenici: „Đuro je Martić poludio". Upravo je razdvajanje imena od prezimena glagolom ,je” u funkciji naglašavanja njegove podvojenosti i intimnog rastrojstva.

\section{2.}

Središnja je ličnost moderne Antun Gustav Matoš (1983: 5) koji se u književnosti prvi put javio pripovijetkom Moć savjesti objavljenom u „Viencu” 1892. godine. U fazi dezintegracije realizma Matoš se predstavlja kao autor kratkih priča koje imaju posve specifičan naziv: iverje, skice, sličice i sl. Stilski su ove priče satkane od oštrog humora, satire, sklonosti prema neobičnom i fantastičnom, poenta je u njima dobro postavljena.

U priči Moć savjesti suprotstavljane su dvije kompozicijske razine, realistična i fantastična. Taj procjep između dviju zbilja prepoznaje se u snu općinskog pisara Jose Cicvarića kojega za primanje mita progone simboli zle savjesti. U završnim prizorima ovoga grotesknog sna dolazi do dvostruke realizacije biblijske metafore vatre; one za očišćenja od grijeha koja se zbiva u junakovu snu i one koja je vezana uz realističnu plohu u kojoj sluškinja mora spaliti uklete štapove.

Na istome je postupku, naglašava Dubravka Oraić Tolić (2013: 154), oblikovana i novela Mišs, u kojoj glavni lik, saznavši da mu je draga, zvana Miš, počinila samoubojstvo, provodi nemirnu noć punu halucinantnih vizija. U objema kratkim pričama autor destabilizira poetiku realističkog mimetizma uvođenjem fantastičnih i grotesknih nizova realiziranih metafora.

Matoševa se kreativna djelatnost kretala između umjetničke proze i publicistike, između književnosti i novinarstva. Za razumijevanje obilježja Matoševe proze, autorica Oraić Tolić uporište prepoznaje u dvama načelima: artizmu i biografiji. Artizam je univerzalno načelo, piše ona, europske umjetnosti na prijelazu XIX. u XX. stoljeće u doba umjetničke moderne. Biografija je ona sastavnica Matoševe umjetnosti koja je njegov artizam učinila osebujnim, ne samo u sklopu hrvatske moderne, nego i u širemu europskom kontekstu kojega je Matoš bio neposrednim sudionikom upravo po svojoj biografiji, četrnaestogodišnjem izbjeglištvu i lutalačkom životu. 
U europskoj se umjetnosti na prijelazu fin de sièclea artizam pojavio na široj duhovnoj i kulturnoj razini kao posljedica sloma pozitivizma odnosno iscrpljivanja mimetičkog načela u realističkoj poetici. Umjetnik u doba fin de sièclea ne opisuje i ne analizira zbilju kao u realizmu, niti je želi negirati i potpuno promijeniti kao što su to činili avangardni umjetnici. On zbilju doživljuje i oblikuje kao svoju vlastitu estetsku konstrukciju. Umjetnost je umjetnikova subjektivna projekcija, ona je sublimacija i rekreacija zbilje. Stoga su artizam, subjektivizam, esteticizam, larpurlartizam itd. osnovna načela umjetnosti na smjeni stoljeća pa nije čudno što Zoran Kravar (2004: 56) predlaže da se tradicionalni književnopovijesni termin moderna zamijeni pojmom esteticizam kako bi se izbjegla terminološka preklapanja između makroepohe društvenopovijesne moderne i književnog razdoblja moderne kao užeg pojma u književnoj povijesti.

A.G.M. afirmator je kratke priče, pa njegove zbirke postaju mjesto iz kojega ovaj žanr kreće u recepcijski snažniji „proboj”. Matoš je u književnost ušao kao pripovjedač simbolističko-groteskno-fantastičnom pričom Moć savjesti u kojoj se binarnost teme i motiva prepoznaje u rascjepu između svijeta jave i svijeta sna, zbilje i fantastike, realnoga i irealnoga, stvarnosti i ideala, objekta i subjekta s nastojanjem da se uspostavi jedinstvo među navedenim oprekama. Igra između dualizma i monizma ostavila je traga na tematskom planu, u fabuli, likovima, kompoziciji i stilu.

Fabula ove priče inicijalno je bizarna, na trenutke rasplinuta, motivirana snom i pomaknutim duševnim stanjem Jose Cicvarića kojega gone štapovi sve do zvijezda. U Mišu se student medicine Milinović, koji je uronjen u svijet vlastite subjektivnosti, odbije oženiti trudnom djevojkom. Djevojka se uslijed toga ubije, a on zapadne u psihičku krizu koja završava bizarnim samoubojstvom. Naime, umjesto da strada samo miš u neobičnoj zamci, postavljen u njoj pištolj opali i osim miša ubija i onoga koji ga je postavio. Matoš u priči ne zadire u unutarnje stanje glavnog lika, već se zadržava samo na njegovu plošnom opisu. Neobične fabule i u ostalim njegovim kratkim pričama nalik su ovoj, a ispričane u brzom ritmu i „enervantnim” kombinacijama. Na taj način one postaju i izraz duboke ontološke krize koja je europsku kulturu i umjetnost zahvatila u vrijeme umjetničke moderne. U modernoj umjetnosti na prijelomu stoljeća vrijedi maksima „svijet je tekst": umjetnost je subjektivna rekonstrukcija svijeta, pa fabula sa svojim logičnim uzročno-posljedičnim vezama više nije važna jer ne može izraziti 
druge sfere svijesti. Jedina funkcija umjetnosti postaje njezina vlastita autonomija. U Matoševim kratkim pričama bizarne su fabule bile način na koji je autor spajao dva svijeta, svijet izvanjske zbilje i svijet mašte, empirije i fantastike, mogućega i nemogućega. Stupanj bizarnosti proporcionalan je stupnju procjepa između tih svjetova. O poetici kratke priče u pismima Milanu Ogrizoviću poslanima iz Beograda 1907. godine A.G.M. piše sljedeće:

Moji ,junaci” redovito umiru, jer ja - ostajem živ, umiru kao simboli mojih proljeća i pokojnih jeseni. Dobro si shvatio nit moje pripovjedačke metode: realne, moje, kontrolisane senzacije, realizovane u sasvim realnim, dobro opserviranim ljudima, a da bude senzacija što veća i jača, roman je stisnut u što uži mider (da curi krv), a monotonija psihološkog doživljaja, da što jače frapira i djeluje, smještena je u što dramatičnije, drastičnije i bizarnije kombinacije, jer - sve se događa, a čita se samo što je „nevjerovatno”, dakle rijetko. Običnu senzaciju rarificirati, kristalizirati - ,eto afere", eto mog literarnog postupka na koji dođoh kao gimnazijalac u Moći savjesti sasvim spontano, našavši tek kasnije analognu metodu kod Poea, Merimeea i našeg Kovačića (...). Ja mislim da svaka priča mora - da tako reknem - biti drukčije napisana, te čitalac kliče: Nije pojmljivo da je to od istog pisca! (...). Ja sam dosele u pričama bio odviše, upravo grozno nesrećan i patetičan, a i studentski naivan, a sada ću biti, mislim, rezak, ajnfah, kratak, humorist, cinik, ironičar i sarkast. Zašto da ne probamo novu žicu? (Matoš 1973: 34).

Matošev pripovjedački opus čine zbirke Iverje (1899), Novo iverje (1900) te Umorne priče (1909). Prema tipovima motiva o kojima je pisao Ivo Frangeš (1974: 123) mogu se čitati kroz pet nizova: 1. priče o našim ljudima i domaćim prilikama, 2. humoreske o našim ljudima kod kuće i u tuđem svijetu, 3. priče o neobičnim, nevjerojatnim „nerealnim” zgodama, 4. priče zanosne ljubavne čežnje i 5. lirske kadence.

Poetika kratke fragmentarne priče s tematskim dvojstvom realnog i irealnog svijeta, sa zgusnutom kompozicijom i postupcima očuđenja prvi je put ostvarena u priči Moći savjesti, što je obilježilo cjelokupni Matošev prozni opus i otvorilo razdoblje hrvatske moderne.

Dominantna stilska obilježja njegove proze kreću se između impresionističke poetike, one ,realistične, s materijalnim stilom” (Oraić Tolić 2013: 56) i simbolističke poetike prožete fantastikom i ,apstraktnim, simbolskim stilom" (Oraić Tolić 2013: 57). U prvoj motivska je građa iz zagrebačkog ili provincijskog života, fabule su građene na stvarnim zbivanjima, a likovi 
su psihološki motivirani. U središtu je priče obično istinit događaj, kao što je građanska pobuna u Zagrebu zbog isticanja mađarskih grbova u Kipu domovine leta 188*. Ona ulazi u krug Matoševe impresionističke pripovjedne proze. Uvodna i završna rečenica pripadaju reportažnom stilu jer sadržavaju izvanjski naratorski glas koji daje osnovne podatke i komentar o građanskoj buni zbog „onijeh grbova”, a tadašnja publika u tome prepoznaje stvarni politički događaj. Epilog završava komentiranjem sudbine bračnog para Pogačić, piljara na Trgu, koji su stradali u tim događajima: „I nju i njega zakopaše krišom - krišom, dragi čitaoče, krišom" (Matoš 1983: 45). Priča je ispričana u duhu impresionističke poetike, s diskretno naznačenim dojmovima o vremenskim prilikama uoči nailaska vojske, s prikazima atmosfere straha na Trgu i opisima prkosa i smrti piljarice Pogačić pod konjskim kopitima: „Uto bocne onaj časnik svog konja i uz urnebesni hura i smijeh preskoči poštovanu 'tovarušicu', općepoznatog purgara Pogačića” (Matoš 1983: 45). Posebice iscrpno analizirao ju je Viktor Žmegač u knjizi Duh impresionizma i secesije naglašavajući njezinu secesijsku minucioznost u prikazu likova. Prema mišljenju Oraić Tolić, Matoš takvu pravilnu impresionističku „sličicu” s kontrastnim stilskim okvirom više nigdje nije ostvario (Oraić Tolić 2013: 130). Motivska građa, zbivanja i likovi nisu oblikovani $\mathrm{u}$ duhu realističke poetike, nego stilskom mješavinom u kojoj važnu sastavnicu čini pripovjedačevo bilježenje zbilje kroz reportažnost i satiru.

\section{3.}

U Matoševim impresionističkim pripovijetkama osjetilni se mimetizam najčešće spaja s reportažnim viđenjem zbilje i anegdotskim poentiranjem. Publicističkim pristupom Matoš prikazuje stvarnost ne dajući viziju cjeline, što bi bilo karakteristično za realističku poetiku. Anegdotski pristup način je da se na sažet način karakterizira vrijeme i prostor bez dugih realističkih opisa i eksplikacija. Upad reportažnosti i anegdote u svijet osjetilnog mimetizma $\mathrm{s}$ jedne strane i miješanje neposredne osjetilnosti $\mathrm{s}$ realističkom građom oslobođenom njezinih funkcija i načina oblikovanja s druge strane, proizveli su onaj neobični spoj artizma i novinarstva, koji je u njegovim impresionističkim pripovijetkama doveo do feljtonizacije umjetničke proze. U drukčijemu rasporedu i na drugome žanrovskom području, 
osobito u feljtonima, ova Matoševa narativna igra dovodi do estetizacije novinarstva.

\section{Literatura}

Čorkalo Jemrić K., 2008, Psihološke novele - stvaralački uspon prema modernizmu, Vinkovci.

Frangeš I., 1974, Matoš, Vidrić, Krleža, Zagreb.

Kravar Z., 2004, Antimodernizam, Zagreb.

Leskovar J., 2005, Misao na vječnost. Propali dvori, Zagreb.

Matanović J., 1997, Čitanje Kozarčeve Oprave, u: eadem, Prvo lice jednine, Osijek, str. 87-103.

Matoš A.G., 1973, Sabrana djela, sv. 19, Pisma I, ur. D. Kapetanić, Zagreb.

Matoš A.G., 1983, Pripovijesti, Zagreb.

Oraić Tolić D., 2013, Čitanja Matoša, Zagreb.

Žmegač V., 1997, Duh impresionizma i secesije. Studije o književnosti hrvatske moderne, Zagreb. 
